\title{
Causality between Economic Growth and Health Expenditure: A time series analysis from 1996 till 2017 in Albania
}

\author{
TEUTA XHINDI \\ Head of the Informatics and Scientific Training Department \\ Mediterranean University of Albania \\ Rr. Todi Shkurti, P.7, Ap.6, Tirana 1010 \\ ALBANIA \\ ERMELA KRIPA \\ Full Professor \\ University Our Lady of Good Counsel \\ ALBANIA \\ KEVIN SHESTANI \\ University of Turin \\ Via Santa Gulia 10, Turin 10126 \\ ITALY
}

\begin{abstract}
Evidence shows that human capital is a leading driver and one of the most important factors affecting economic development. Economic growth models emphasize the effect that human capital has on the growth and prosperity of a country. The indicators used to measure human capital vary. In this article we will use total health expenditure as a measure for human capital. A healthier population will obviously lead to increased productivity and consequently a higher income for the individual. By increasing public health investments, the workforce will potentially be healthier and consequently human productivity will increase. One of the most important lessons to be learned from the coronavirus pandemic is the importance of investments in health care services, human resources and technical infrastructure for the economy. The aim of this article is to study the relationship between Health Care Expenditure (HCE) per capita and Gross Domestic Product GDP per capita in Albania. The data (in \$) is taken from the World Health Organization website, for the time period 1996-2017. The methods used are the ARDL Bounds testing approach for co-integration and the Granger causality test. The main results are: the variables per capita GDP and per capita HCE are not cointegrated. The $\operatorname{ARDL}(1,1)$ model estimation points out the positive relationship between the two variables. Also, our study confirms the existence of joint causality between per capita GDP and per capita HCE.
\end{abstract}

Key words: economic growth, health care expenditure per capita, human capital investment, GDP per capita, total health expenditure, growth models.

Received: November 22, 2019. Revised: April 12, 2020. Accepted: May 7, 2020. Published: May 11, 2020.

\section{Introduction}

After the fall of the communist regime, a series of important reforms were undertaken in Albania which ensured a rapid GDP growth rate of 9.3\% from 1993 to 1996 (World Bank, 2009). After 1997, in the period 1998-2008, economic growth rate was approximately $6 \%$. As a result of the 2008 global financial crisis, Albania was affected mainly by the recession of neighboring countries, Greece and Italy, and this was reflected in an evident economic decline. 2013 marked the lowest rate of economic growth with 1\%. After 2013, there has been a constant improvement, with rates reaching the highest value in 2018 with $4.1 \%$. This growth has resulted from several large projects of foreign investors, especially in the field of energy such as the TAP project and the improvement of the economic ecosystem of EU countries, being Albania's main trading partners (IMF, 2017). With lower rainfall slashing energy production, growth is projected to slow down to 2.9 percent in 2019 (World Bank, 2019). 
According to the Institute of Statistics INSTAT, the Albanian population on January $1^{\text {st }}, 2019$ was 2.86 million, experiencing a $0.3 \%$ decrease compared to the previous year. Public expenditure in the health sector in 2017 was ALL 45,532 billion. These costs represent $10.29 \%$ of the total public spending for 2018 and $3.01 \%$ of the total GDP. Compared to 2017, public health spending as a percentage of GDP has increased by $3.1 \%$, while public health spending as a percentage of total public spending has increased by $4.7 \%$ (INSTAT, 2019).

The total number of deaths in 2018 was 21,804 , a decrease of $1.9 \%$ compared to the previous year. In total, $93.8 \%$ were deaths by natural causes; accidents are the second leading cause of reported deaths in the country, which in the four-year time frame remains unchanged (INSTAT, 2019). A higher rate of investment in the healthcare sector would obviously lead to a healthier population, consequently increased productivity and hence more income for individuals.

This article presents an attempt to study the relationship between per capita Total Health Expenditure and per capita GDP in Albania using time series data from 1996 till 2017.

\section{Research aim and objectives}

Although many authors have studied the relationship that exists between healthcare investments and economic growth, few such studies have been conducted for the Albanian context. Health, other than being a value in itself, is also a precondition for a prosperous economy as it directly influences economic outcomes such as productivity, the supply of labor, productivity and human capital. This article demonstrates that increasing investments in the healthcare system would potentially be highly beneficial to the economic performance of Albania.

\subsection{Aim}

The aim of this article is to investigate the relationship between: per capita GDP and per capita Health care expenditure in Albania using time series data from 1996 till 2017.

\subsection{Objectives}

1.Thorough analysis of the relevant theoretical literature in order to select Health Care Expenditure as a proxy for Human Capital.

2.Thorough analysis of the relevant empiric and theoretical literature with respect to the relationship between Economic Growth and Health Care Expenditure.
3.To test for stationarity and co-integration between per capita GDP and per capita Health care expenditure in Albania using time series data from 1996 till 2017.

4.Granger Causality test to determine the direction of causality between per capita GDP and per capita Health care expenditure in Albania using time series data from 1996 till 2017.

5.Empirical analysis to conclude if it exists a positive relationship between per capita GDP and per capita Health Care Expenditure using ARDL $(1,1)$ model.

\section{3 Hypothesis:}

There is a positive relationship between Economic Growth and per capita Health Expenditures in the Albanian context.

The rest of this article is structured as follows: In section 3 we will provide the arguments why health care expenditure is used as a proxy for human capital. The literature review is discussed in section 4. The variables' description and econometric methodology is described in section 5. Section 6 presents the empirical results, conclusions and future work.

\section{Health Care Expenditure as a proxy for Human Capital}

Economic growth is commonly referred to as one of the most important indicators of a country's wellbeing and development. In order to thoroughly understand economic growth, we need to identify the factors underlying it. Models of economic theory help us understand the factors that lead to economic growth and the differences in growth rates among countries (Elboiashi, 2011). In fact, understanding the factors that determine economic growth is of great interest, not only to researchers but also to policymakers. Adam Smith in 1776 laid the foundation for research on theories of economic growth and was followed by many scholars over the centuries, such as David Ricardo, Schumpeter (1934), Harrod (1939), Domar (1946), Solow (1956), Swan (1956), Romer (1986), Lucas (1988), Pietak (2014) etc. For study purposes, economic growth theories are divided into two categories: neoclassical growth theories, where factors causing economic growth are treated as exogenous, and the new growth theory, which treats growth factors as endogenous.

\subsection{The neoclassical growth theory}

The neoclassical growth theory, commonly known as the exogenous growth model, was firstly 
developed by Solow and Swan in 1956 and 1957. Their model is the starting point for almost all analyzes of economic growth. The theory assumes that economic growth is generated through the accumulation of production factors, such as capital and labor stock, technological development and population growth. In their model of economic growth, Solow and Swan emphasize the importance of technological development in economic growth, but do not clearly describe the way technology develops, nor do they clearly explain its impact on the economy. This theory is characterized by declining returns on capital and does not explain economic growth in the long run. The exogenous growth model, although simple to understand and apply, has some disadvantages that accompany it. This theory does not analyze the links that exist internally between the factors of production.

The neoclassical growth theory does not adequately explain the economic growth and the way technology, knowledge and information are disseminated. It is also criticized by many for its definition of human capital, referred to it as physical capital. But Mincer (1981) and Becker (1975) argue that human capital is far more complex and should be widely interpreted. Human capital, according to them, is no longer homogeneous, as it is not only physical, but it can be enriched by investing in education, health, etc.

\subsection{The new growth theory}

In the mid-1980s, exogenous growth theory resulted inadequate in explaining long-term economic growth and eventually is was substituted by the new growth theory (Barro and Sala-I-Martin, 1995). The neoclassical growth theory could not explain why similar factors of production do not produce similar economic growth in the countries considered in the study.

This is because neoclassical growth theory treats human capital as physical capital, not adding knowledge, expertise, and skills developed through research and development to it. It is precisely this broader concept of human capital according to endogenous growth theories that avoids diminishing returns to capital, as improved human capital can promote innovation (Romer, 1986, 1990; Lucas, 1988). Developing human capital would facilitate economic growth through the usage of new technologies and efficient production techniques. The increase in human capital will then lead to economic growth. As internal models of economic growth focus on the development of human capital, let's have a look at how different authors define or measure human capital.
According to Goldin, human capital can be defined as the stock of productive skills, talents, health and expertise of the labor force, just as physical capital is the stock of plants, equipment, machines, and tools. Within each type of capital performance, quality and efficiency can vary (Goldin, C. 2014). Many authors measure human capital based on years of education, but recently the optics of measuring human capital has changed, focusing primarily on the quality of education.

Recently, a great importance has been given to human capital in the perspective of public health investment. By investing more in this sector, the workforce will be healthier and consequently

human productivity will increase.

At the heart of Galor and Weil (2000) models and later of Galor's (2011) model it's the role that human capital plays in economic growth. The model contains three regimes and the decisionmakers are the parents who determine how many kids to have and how much to invest in each one of them. At the outset there are low levels of income, no schooling, no income growth, and a very low increase in population. As population increases, technology advances.

Our article will focus on the importance of human capital on economic growth. To accomplish this, we have relied on new approaches to measuring human capital. In our model, human capital is linked to health and income, so increased resources allow people to invest more in their health. And, on the other hand, more human health capital allows people to be more productive.

In the discussion that follows, the causation will mainly go from increased resources to advances in health human capital. There are different measures of health human capital. In our study, we will consider the definition given by UNDP based on the reported Human Development Index (HDI). Definition: The Human Development Index (HDI) is a statistical tool used to measure a country's overall achievement both socially and economically. The social and economic dimensions of a country are based on the health of people, their level of education and their standard of living.

Since it was first published in the Human Development Report of 1990, it has become widely accepted as a global yardstick for the development performance of nations and a starting point for drawing up rankings. Pakistani economist Mahbub ul Haq created HDI in 1990, used later to measure the country's development by the United Nations Development Program (UNDP). The calculation of the index combines four major indicators: life 
expectancy for health, expected years of schooling, mean of years of schooling for education and Gross National Income per capita for standard of living. Every year UNDP ranks countries based on the HDI report released in their annual report. HDI is one of the best tools to keep track of the level of development of a country, as it combines all major social and economic indicators that are responsible for economic development.

This indicator went through an important development in 2010, year in which Health, Education and Income were taken into account for its calculation.

According to this new approach, we measure Human Capital with Total Health Expenditure.

\section{Literature review}

The relationship between Health care expenditure and Economic Growth has been treated by different authors and there are some notable results in regard.

The first authors to study the link between health care expenditure and economic growth were Kleiman (1974) and Newhouse (1977). According to them, there is a strong positive relationship between HCE and GDP growth for developed countries. They also argued that GDP also explains a high percentage of the volatility of HCE.

According to Newhouse, per capita income can explain differences in health spending across countries, and a country should find ways by which to ration services consistent with its income despite variation in out-of-pocket prices paid by the consumer in different countries.

Also, the link between income and health care expenditures was examined by Gerdtham and Löthgren (2000) and they concluded that both health care expenditure (HCE) and GDP are nonstationary and cointegrated. Similarly, Baltagi and Moscone (2010), in a study made for 20 OECD countries with panel data for the 1971-2004 period, concluded that health care is a necessity rather than a luxury.

Recent health literature has emphasized the importance of technological change as an explanation for the rising health share. According to Hall and Jones (2007), this is a proximate rather than a fundamental explanation. The most obvious explanation in the model they proposed was: new and expensive technologies are valued because of the rising value of life.

Erçelik, G. (2018) concluded that there is a positive relationship between GDP per capita, public and private spending for health and investment in the long- run. Besides this, the author states that health and investment affect GDP per capita in a positive way since the productivity of the country is improved. In this article, the ARDL model is used with annually data from 1980-2015 for Turkey.

In their paper, Eggoh, Houeninvo and Sossou (2015) found out that education and health expenditure have a negative effect on economic growth. According to the authors, this negative effect is probably as a result of corruption, bureaucracy and underinvestment. They used panel data from 49 African countries for the period 19962010.

Hasan and Kalim (2012) used time series data from 1972-2009, for education, health and economic growth for Pakistan. The authors concluded that it exists a two-way causality between economic growth/capita and education \& health expenditures/capita in the long run.

Karim (2016) discovered that health care expenditure has a weak impact on economic growth by using the Autoregressive Distribution Lag Model, using data for Nigeria from 1985-2009. Pradhan (2010) found out that a reciprocal relationship exists between health care expenditure and economic growth, using panel data from 19612007 for Austria, Canada, Finland, Iceland, Ireland, Japan, Norway, Spain, Switzerland, UK and USA.

\section{Methodology and Empirical Study}

\section{1 Variable description}

Total expenditure on health HCE: Total Health Expenditure is defined as the sum of public and private health spending.

Public sector spending is current and capital expenditure, financed by central or local government budgets, loans taken abroad or grants (including donations from international agencies and non-governmental organizations) as well as from health insurance contributions.

The private sector includes direct out-of-pocket payments made by individuals, private insurance, charity gifts, and direct payments of the services of private organizations serving individuals (ex. NGOs)

GDP is the value of all goods and services provided in a country by residents and nonresidents without regard to their allocation among domestic and foreign claims. This corresponds to the total sum of expenditure (consumption and investment) of the private and government agents. Per capita GDP is obtained by dividing total GDP on total population for each year from 1996 - 2017. 
Per capita Health Care Expenditure is obtained by dividing the total health expenditures on total population for each year from $1996-2017$.

\subsection{Data source}

In order to study the relationship between the two variables GDP/capita and $\mathrm{HCE} /$ capita in the Albanian context, we have utilized data taken from the website of the World Health Organization, corresponding to the 1996-2017 time period. The data currency is $(\$)$.

Figure 1: Graphs of per capita $(\mathrm{GDP})_{t}$ and per capita $(\mathrm{HCE})_{t}$ for the $1996-2017$ time period in Albania.

The graphic presentation of GDP/capita and HCE/capita from 1996-2017

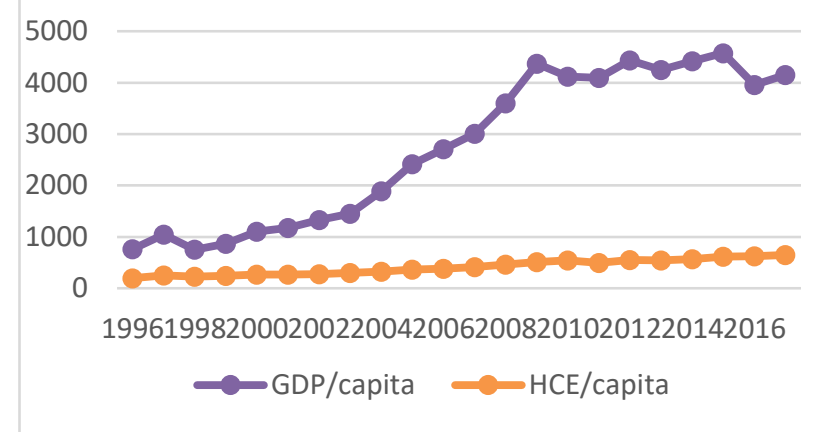

Data ranks Albania as the country that spends the least per capita on healthcare in the region. Calculating the average HCE per capita in the period 2012-2017 puts Albania at the bottom position in the region with $\$ 592$ / capita.

Since 2005, total per capita spending has increased, but still this growth has resulted insufficient in comparison to neighboring countries like North Macedonia and Montenegro. Furthermore, the 'healthcare expenditure to GDP' ratio is considerably lower compared to other European countries. In 2015 , this ratio was equal to $2.2 \%$, at a time when according to EUROSTAT the average expenditure on healthcare in the EU was $7.2 \%$ of GDP in 2015 and $9.6 \%$ of GDP in 2017. Another current issue is the allocation of funding and administration of various public health services to multiple concessionaire companies that have dubious measurable performance and low levels of transparency.

The two variables, per capita (GDP) $t$ and per capita $(\mathrm{HCE})_{t}$, are transformed in logarithmic form aiming to improve the normal distribution and leave out outliers, so:

$$
\begin{aligned}
& (\mathrm{GDP} 1)_{t}-\operatorname{Ln}\left((\mathrm{GDP})_{t} / \text { Capita }\right) \\
& (\mathrm{HCE} 1)_{t}-\operatorname{Ln}\left((\mathrm{HCE})_{t} / \text { Capita }\right)
\end{aligned}
$$

The Descriptive Statistics table for both variables is shown below:

Table 1: Descriptive statistics table for (GDP1) $t$ and $($ HCE1) $t$

\begin{tabular}{|c|c|c|}
\hline Statistics & $(\mathrm{GDP} 1)_{t}$ & $(\mathrm{HCE} 1)_{t}$ \\
\hline Mean & 7.73 & 5.95 \\
\hline Median & 7.96 & 5.98 \\
\hline Maximum & 8.43 & 6.47 \\
\hline Minimum & 6.62 & 5.28 \\
\hline Std. Dev. & 0.67 & 0.38 \\
\hline Skewness & -0.45 & -0.19 \\
\hline Kurtosis & 1.6 & 1.6 \\
\hline J-B Probability & 0.28 & 0.38 \\
\hline Observations & 22 & 22 \\
\hline
\end{tabular}

The correlation coefficient between $(\mathrm{GDP} 1)_{t}$ and $(\mathrm{HCE} 1)_{t}$ is $\approx 0.976335$

The mean and median values are between the minimum and maximum values and Probability J-B values ensure the normal distribution for both variables.

According to IMF, per capita income in Albania for 2017 was $\$ 4,520$, ranking 105th out of 189 countries analyzed. Eurostat data indicates that with these figures, Albania remains at the level of $30 \%$ of the EU average. Data on per capita income over the years shows that Albania has failed in increasing the well-being of its citizens compared to countries in the same region and beyond. In 2006, per capita income was $\$ 3,000$ and Albania was slightly better positioned in 104th place.

Figure 2: The graphs of (GDP1) $t$ and (HCE1) $t$ for the period 1996-2017 period

The graphic presentation of GDP1 and HCE1 from 1996-2017

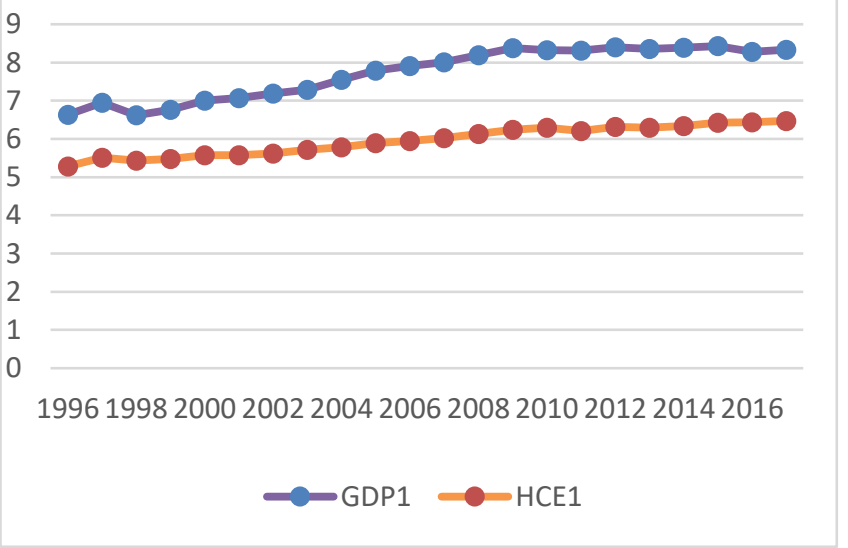




\section{3 Data Analysis}

\section{Testing for stationarity}

To empirically analyze the long-run relationship between per capita GDP and per capita health care expenditure the bounds testing approach is used. Bounds testing is applicable when the series are both $\mathrm{I}(0)$ or $\mathrm{I}(1)$ or mixed but not when the series are $\mathrm{I}(2)$.

So, it is necessary to initially test the (GDP1) $t$ and $($ HCE1) $t$ series for stationarity. The test used is the Augmented Dickey - Fuller for unit roots.

The results for all three cases, for both series (GDP1) $\mathrm{t}$ and (HCE1) $\mathrm{t}$ are shown below.

Table 2: ADF test results for unit roots for (GDP1)

\begin{tabular}{|c|c|c|}
\hline \multicolumn{2}{|c|}{$\begin{array}{c}\text { Null Hypothesis: (GDP1) } \mathrm{t} \text { has a } \\
\text { unit root }\end{array}$} & \\
\hline $\begin{array}{c}\text { Exogenous: } \\
\text { None }\end{array}$ & $\begin{array}{c}\text { Exogenous: } \\
\text { Constant, Linear } \\
\text { Trend }\end{array}$ & $\begin{array}{c}\text { Exogenous: } \\
\text { Constant }\end{array}$ \\
\hline $\mathrm{p}=0.9841$ & $\mathrm{p}=0.9563$ & $\mathrm{p}=0.4866$ \\
\hline
\end{tabular}

Table 3: ADF test results for unit roots for (HCE1)

\begin{tabular}{|c|c|c|}
\hline \multicolumn{3}{|c|}{ Null Hypothesis: (HCE1) $\mathrm{t}$ has a unit root } \\
\hline $\begin{array}{c}\text { Exogenous: } \\
\text { None }\end{array}$ & $\begin{array}{c}\text { Exogenous: } \\
\text { Constant, Linear } \\
\text { Trend }\end{array}$ & $\begin{array}{c}\text { Exogenous: } \\
\text { Constant }\end{array}$ \\
\hline $\mathrm{P}=0.9997$ & $\mathrm{P}=0.3978$ & $\mathrm{P}=0.6221$ \\
\hline
\end{tabular}

As $\mathrm{p}$-values are greater than $\alpha=0.05$, we conclude that both series are not stationary.

After that, the variables are tested in first difference for stationarity using again the ADF test and both variables became stationary at $5 \%$ level of significance.

Table 4: ADF test results for unit roots for $\mathrm{D}(\mathrm{GDP} 1)_{\mathrm{t}}$

\begin{tabular}{|c|c|c|}
\hline \multicolumn{3}{|c|}{ Null Hypothesis: $\mathrm{D}(\mathrm{GDP} 1)_{\mathrm{t}}$ has a unit root } \\
\hline $\begin{array}{c}\text { Exogenous: } \\
\text { None }\end{array}$ & $\begin{array}{c}\text { Exogenous: } \\
\text { Constant, Linear } \\
\text { Trend }\end{array}$ & $\begin{array}{c}\text { Exogenous: } \\
\text { Constant }\end{array}$ \\
\hline $\mathrm{P}=0.0002$ & $\mathrm{p}=0.0031$ & $\mathrm{p}=0.0007$ \\
\hline
\end{tabular}

Table 5: ADF test results for unit roots for $\mathrm{D}(\mathrm{HCE} 1)_{\mathrm{t}}$

\begin{tabular}{|c|c|c|}
\hline \multicolumn{3}{|c|}{ Null Hypothesis: $\mathrm{D}(\mathrm{HCE} 1)_{\mathrm{t}}$ has a unit root } \\
\hline $\begin{array}{c}\text { Exogenous: } \\
\text { No(HCE1) } \mathrm{t} \text { ne }\end{array}$ & $\begin{array}{c}\text { Exogenous: Constant, } \\
\text { Linear Trend }\end{array}$ & $\begin{array}{c}\text { Exogenous: } \\
\text { Constant }\end{array}$ \\
\hline $\mathrm{P}=0.0022$ & $\mathrm{p}=0.0001$ & $\mathrm{p}=0.0000$ \\
\hline
\end{tabular}

So, both series $\mathrm{D}(\mathrm{GDP} 1)_{\mathrm{t}}$ and $\mathrm{D}(\mathrm{HCE} 1)_{\mathrm{t}}$ are stationary.

\section{Testing for Co-integration}

Before testing for co-integration between (GDP1) $t$ and (HCE1)t, it is necessary to select an appropriate lag order of the variables.

Table 6. Lag order selection criteria

VAR Lag order selection criteria

\begin{tabular}{|c|c|c|c|c|c|c|}
\hline Lag & $\log \mathrm{L}$ & LR & FPE & AIC & $\mathrm{SC}$ & HQ \\
\hline 0 & 10.77140 & NA & 0.022114 & -0.974600 & $\begin{array}{c}- \\
0.875670 \\
- \\
1.632098\end{array}$ & $\begin{array}{c}- \\
0.960959 \\
- \\
1.760031\end{array}$ \\
\hline 1 & 19.02444 & $13.75506^{*}$ & $0.009900 *$ & $-1.780493^{*}$ & * & $\begin{array}{l}* \\
-\end{array}$ \\
\hline 2 & 19.34780 & 0.503002 & 0.010720 & -1.705311 & $\begin{array}{c}1.507450 \\
-\end{array}$ & $\begin{array}{c}1.678028 \\
-\end{array}$ \\
\hline 3 & 19.34809 & 0.000431 & 0.012069 & -1.594233 & $\begin{array}{c}1.346907 \\
-\end{array}$ & $\begin{array}{c}1.560130 \\
-\end{array}$ \\
\hline 4 & 21.95306 & 3.473293 & 0.010214 & -1.772563 & 1.475772 & 1.731639 \\
\hline
\end{tabular}

\footnotetext{
* indicates lag order selected by the criterion

LR: sequential modified LR test statistic (each test at 5\% level)

FPE: Final prediction error

AIC: Akaike information criterion

SC: Schwarz information criterion

HQ: Hannan-Quinn information criterion
}

Table 6 presents the lag order of the variables selected by different tests. As the value computed by Akaike Information criterion, $-1.780493^{*}$, is the smallest among them, the lag order of the variables 1 is selected by using AIC criteria. After that, we can test for co-integration between variables $(\mathrm{GDP} 1)_{\mathrm{t}}$ and $(\mathrm{HCE} 1)_{\mathrm{t}}$.

It is necessary to perform a co-integration test in order to establish the long-run relationship between two variables. In our article, we have examined for 
co-integration between two variables using the ARDL bound testing approach, considering the restricted number of observations.

First, Bounds testing was proposed by Pesaran, Shin and Smith (2001) and it is used with variables on level form or by using the log transformation of the raw variables (as in our case).

The hypothesis for this test, are as follows:

$H_{0}$ :The two variables are not co-integrated

$H_{1}$ :The two variables are co-integrated

The significance level used is 5\%. Decision Criteria for Bounds Test:

If the calculated F-statistic is greater than the critical value for the upper bound I(1), than we reject the null hypothesis and conclude that the two variables are co-integrated.

If the calculated F-statistic is lower than the critical value for the lower bound I(0), than we can't reject the null hypothesis and conclude that the two variables are not co-integrated.

If the calculated F-statistic falls between the lower bound $\mathrm{I}(0)$ and the upper bound $\mathrm{I}(1)$, than the test is considered inconclusive.

We will perform ARDL Bounds Test for the models:

$G D P 1_{t}=c+G D P 1_{t-1}+H C E 1_{t}+H C E 1_{t-1}+u_{1 t}$

$H C E 1_{t}=k+H C E 1_{t-1}+G D P 1_{t}+G D P 1_{t-1}+u_{2 t}$ (2)

The tables below present the results for ARDL Bounds Testing Approach for co-integration for models (1) and (2)

Table 7. ARDL Bounds Testing Approach for Cointegration for model (1)

\begin{tabular}{lcccc} 
F-Bounds Test & \multicolumn{4}{c}{$\begin{array}{l}\text { Null Hypothesis: No levels } \\
\text { relationship }\end{array}$} \\
\hline \hline Test Statistic & Value & Signif. & $\mathrm{I}(0)$ & $\mathrm{I}(1)$ \\
\hline \hline & & & \multicolumn{3}{c}{ Asymptotic } \\
& & & $: \mathrm{n}=1000$ \\
F-statistic & 0.779283 & $10 \%$ & 4.04 & 4.78 \\
K & 1 & $5 \%$ & 4.94 & 5.73 \\
& & $2.5 \%$ & 5.77 & 6.68 \\
& & $1 \%$ & 6.84 & 7.84
\end{tabular}

Table 8. ARDL Bounds Testing Approach for Cointegration for model (2)

\begin{tabular}{lcccc} 
F-Bounds Test & \multicolumn{4}{c}{$\begin{array}{c}\text { Null Hypothesis: No levels } \\
\text { relationship }\end{array}$} \\
\hline \hline Test Statistic & Value & Signif. & $\mathrm{I}(0)$ & $\mathrm{I}(1)$ \\
\hline \hline & & \multicolumn{3}{c}{ Asymptotic } \\
& & & $\mathrm{n}=1000$ \\
F-statistic & 2.884756 & $10 \%$ & 3.02 & 3.51 \\
K & 1 & $5 \%$ & 3.62 & 4.16 \\
& & $2.5 \%$ & 4.18 & 4.79 \\
& & $1 \%$ & 4.94 & 5.58
\end{tabular}

Clearly, the F-statistic is lower than the lower bound $\mathrm{I}(0)$ for all significance levels in both tables above, so we can't reject the null hypothesis. The variables are not co-integrated, consequently there is only a short run relationship between the variables, meanwhile in the long run a relationship between (GDP1) $)_{t}$ and (HCE1) $)_{t}$ doesn't exist.

\section{Estimation of ARDL $(1,1)$ Models}

As between the variables there is no long run relationship, we have estimated the short run models which are the autoregressive distributed lag models:

$$
\begin{aligned}
& \Delta(G D P 1)_{t}=c+\alpha_{1} \Delta(G D P 1)_{t-1}+\alpha_{2} \Delta(H C E 1)_{t}+ \\
& \alpha_{3} \Delta(H C E 1)_{t-1}+u_{1 t} \\
& \Delta(H C E 1)_{t}=k+\beta_{1} \Delta(H C E 1)_{t-1}+\beta_{2} \Delta(G D P 1)_{t}+ \\
& \beta_{3} \Delta(G D P 1)_{t-1}+u_{2 t}
\end{aligned}
$$

The tables below present the estimation output for model (3) and the results of some diagnostic tests such as: the J-B Normality test, Breusch-Godfrey LM test, Breusch-Pagan-Godfrey, Ramsey RESET Test as well as values for Adjusted R-Square and prob (F-statistic).

Table 9. The estimated ARDL $(1,1)$ model (3)

\begin{tabular}{|c|c|c|c|c|}
\hline Variable & $\begin{array}{c}\text { Estimated } \\
\text { coefficients }\end{array}$ & S.E & $\begin{array}{c}\mathrm{t}- \\
\text { statistic }\end{array}$ & $\begin{array}{c}\text { P- } \\
\text { value }\end{array}$ \\
\hline $\mathrm{C}$ & 0.01 & 0.049 & 0.19 & 0.85 \\
\hline$\Delta(G D P 1)_{t-1}$ & -0.02 & 0.29 & -0.08 & 0.94 \\
\hline$\Delta(H C E 1)_{t}$ & 1.64 & 0.55 & 2.99 & 0.0087 \\
\hline$\Delta(H C E 1)_{t-1}$ & -1.46 & 0.69 & -2.11 & 0.049 \\
\hline
\end{tabular}


Table 10. The Results of some Diagnostic tests

\begin{tabular}{|l|l|l|}
\hline Diagnoctic Test & Statistics & $\mathrm{p}$-value \\
\hline J-B Normality & J-B statistics $=0.914$ & 0.63 \\
\hline B-G LM test & $\begin{array}{l}\text { Obs*R-squared } \\
\text { statistics }=1.09\end{array}$ & $\begin{array}{l}0.58 \\
(\mathrm{df}=2)\end{array}$ \\
\hline B-P-G test & $\begin{array}{l}\text { Obs*R-squared } \\
\text { statistics }=2.61\end{array}$ & $\begin{array}{l}0.46 \\
(\mathrm{df}=3)\end{array}$ \\
\hline $\begin{array}{l}\text { Adjusted R- } \\
\text { Square }\end{array}$ & 0.455 & \\
\hline Prob(F-statistic) & & 0.005 \\
\hline $\begin{array}{l}\text { Ramsey RESET } \\
\text { test }\end{array}$ & $\mathrm{t}-$-statistic $=0.826$ & $\begin{array}{l}0.4218 \\
(\mathrm{df}=15)\end{array}$ \\
\hline
\end{tabular}

Tables 9 and 10 demonstrate that the ARDL $(1,1)$ (3) model is a good fit for our data and health care expenditure in the current period and one period lagged are statistically significant. Furthermore, health care expenditure in the current period positively affects GDP per capita while health care expenditure one period lagged negatively affects GDP per capita.

Table 11. The estimated ARDL $(1,1)$ model (4)

\begin{tabular}{|c|c|c|c|c|}
\hline Variable & $\begin{array}{c}\text { Estimated } \\
\beta\end{array}$ & S.E & $\begin{array}{c}\mathrm{t}- \\
\text { statistic }\end{array}$ & $\begin{array}{c}\text { P- } \\
\text { value }\end{array}$ \\
\hline $\mathrm{C}$ & 0.04 & 0.01 & 2.96 & 0.0092 \\
\hline$\Delta(H C E 1)_{t-1}$ & -0.44 & 0.23 & -1.96 & 0.0673 \\
\hline$\Delta(G D P 1)_{t}$ & 0.22 & 0.07 & 2.99 & 0.0087 \\
\hline$\Delta(G D P 1)_{t-1}$ & 0.19 & 0.09 & 2.07 & 0.0550 \\
\hline
\end{tabular}

Table 12. The results from some diagnostic tests

\begin{tabular}{|l|l|l|}
\hline $\begin{array}{l}\text { Diagnoctic } \\
\text { Test }\end{array}$ & Statistics & $\mathrm{p}$-value \\
\hline J-B Normality & J-B statistics $=2.48$ & 0.29 \\
\hline B-G LM test & $\begin{array}{l}\text { Obs*R-squared } \\
\text { statistics }=1.90\end{array}$ & $0.39(\mathrm{df}=2)$ \\
\hline B-P-G test & $\begin{array}{l}\text { Obs*R-squared } \\
\text { statistics }=0.97\end{array}$ & $0.81(\mathrm{df}=3)$ \\
\hline $\begin{array}{l}\text { Adjusted R- } \\
\text { Square }\end{array}$ & 0.55 & 0.001 \\
\hline $\begin{array}{l}\text { Prob(F- } \\
\text { statistic) }\end{array}$ & $\mathrm{t}$-statistic $=0.265$ & $0.8(\mathrm{df}=15)$ \\
\hline $\begin{array}{l}\text { Ramsey } \\
\text { RESET test }\end{array}$ & & \\
\hline
\end{tabular}

Tables 11 and 12 demonstrate that the ARDL $(1,1)$ (4) model is a good fit for our data and that only GDP per capita in the current period is statistically significant. In addition, GDP per capita in the current period positively affects health care expenditure. The fact that $(G D P 1)_{t-1}$ is not statistically significant, can be explained by the fact that health expenditure is planned by the government for each year.

The cumulative sum (CUSUM) plots for both models (3) and (4) also indicate stability in the coefficients over the sample period as in both cases the blue lines are within the bounds at 5\% significance level.

Figure 3: Plot of Cusum for Coefficients Stability for Models (3) and (4)

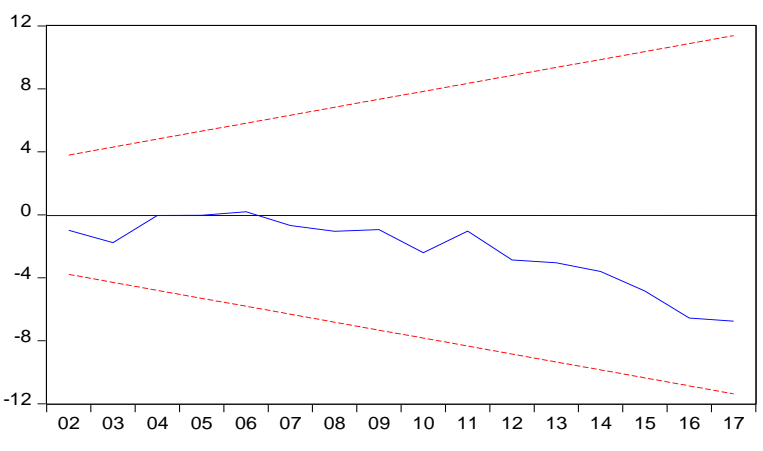

_ CUSUM --.- 5\% Significance

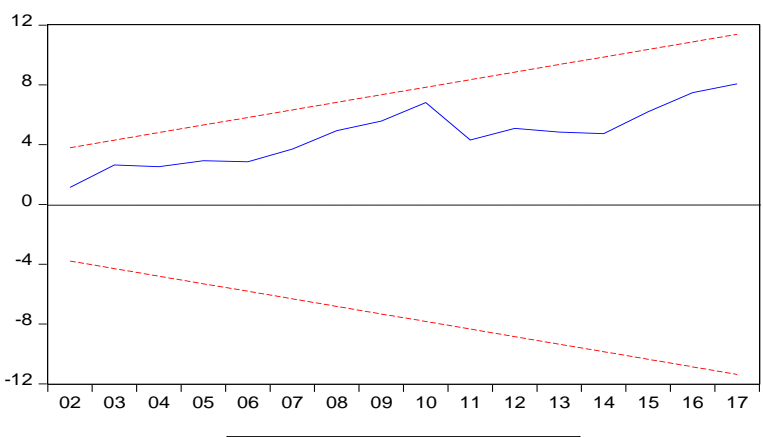

_ CUSUM ----- 5\% Significance

\section{Granger Causality test}

The final step is identifying the direction of causality. To test for causality, we will use the Granger causality test. As for this test the variables are assumed to be stationary, it is necessary to operate with the variables $\Delta(\mathrm{GDP})_{t}$ and $\Delta(\mathrm{HCE} 1)_{t}$. Using the results of table 6 , the lag order of variables is 1 .

The Granger Causality test involves estimating the pair of regressions:

$\Delta(\text { HCE1 })_{t}=\mathrm{c}+\alpha_{1} \Delta(\mathrm{GDP} 1)_{t-1}+\alpha_{2} \Delta(\mathrm{HCE} 1)_{t-1}+u_{1 t}$

$\Delta(\mathrm{GDP} 1)_{t}=\mathrm{k}+\beta_{1} \Delta(\mathrm{GDP} 1)_{t-1}+\beta_{2} \Delta(\mathrm{HCE} 1)_{t-1}+u_{2 t}$ 
Where it is assumed that the disturbances $u_{1 t}$ and $u_{2 t}$ are uncorrelated.

Equation (5) postulates that the current $(\mathrm{HCE} 1)_{t}$ is related to past values of itself as well as that of $(\mathrm{GDP} 1)_{t}$ and equation (6) postulates a similar behavior of (GDP1) $t$.

Table 13 shows the results of the Granger Causality test.

Table 13: Granger Causality test results

\begin{tabular}{|c|c|c|}
\hline \multicolumn{3}{|c|}{ Granger Causality test results } \\
\hline \multicolumn{3}{|c|}{} \\
\hline $\begin{array}{c}\text { Lag } \\
1\end{array}$ & Null Hypothesis & Prob \\
\hline & $\Delta(\text { HCE1 })_{t}$ does not Granger Cause & \\
& D(GDP1 $)_{t}$ & 0.0206 \\
\hline & $\Delta(\text { GDP1 })_{t}$ does not Granger Cause & \\
& D (HCE1 $)_{t}$ & 0.0127 \\
\hline
\end{tabular}

From Table 13, as the $\mathrm{p}$ values are both smaller than $\alpha=5 \%$, the null hypothesis is rejected. So, for Lag 1, causality goes in both directions: $(\mathrm{HCE} 1)_{t} \rightarrow(\mathrm{GDP} 1)_{t}$ and $(\mathrm{GDP} 1)_{t} \rightarrow(\mathrm{HCE} 1)_{t}$

\section{Conclusions}

This article examined the relationship between Economic Growth and Health Care Expenditure per capita in the Albanian context for the 1996-2017 period by using ARDL $(1,1)$ models. The results indicate that in the current period GDP per capita has a positive relationship with Health Care Expenditure per capita.
Applying the ARDL Bounds Testing Approach for Co-integration we found out that the series per capita GDP and per capita HCE are not cointegrated. ARDL Bounds test was performed after AIC indicated the lag order of the variables 1. After performing the stationarity tests, differencing the series was necessary before performing the Granger Causality test. The results of the Granger Causality test indicate that in the Albanian context causality goes in both directions.

Policy Implications: This study confirms that human capital based on health expenditure plays a major role in economic growth. Considering our results and the critical situation of Albania during the Covid-19 pandemic, we suggest that the government should invest considerably more in human and technical resources so that similar future events could be managed more effectively. In addition, a considerable amount of work has to be done to strengthen the health systems' efficiency and effectiveness in order to produce positive health outcomes (to ameliorate the overall health of the population), increase healthcare accessibility (access to medical treatment and essential resources so as to avoid the exclusion of fractions of the population from receiving various healthcare services), and lastly to improve the resilience and pliability of health systems (fiscal sustainability, fast adaptation to morphing environments and the identification of innovative solutions to deal with challenges possessing limited resources).

Future work: One of our future study goals is analysis of the relationship among economic growth, total health care expenditure and education, considering education as one of the key factors influencing a country's economic growth. 
References:

[1] Baltagi, B.H., Moscone, F., "Health Care Expenditure and Income in the OECD Reconsidered: Evidence from Panel Data", Economic Modelling, Issue.4, Vol.27, 2010, pp. 804-811.

[2] Cakërri, L., "The impact of foreign direct investments on economic growth in Albania", Doctoral Thesis, 2019.

[3] Eggoh, J., Houeninvo, H., \& Sossou, G.A., "Education, health and economic growth in African countries". Journal of Economic Development, 40(1), 2015, pp. 93-111.

[4] Erçelik, G., "The Relationship between health expenditure and GDP per capita in Turkey from 1980 to 2015". Journal of Politics, Economy and Management, Volume 1, Issue 1, 2018, pp. 1-8.

[5] Galor, O., \& David W., "Population, Technology, and Growth: From the Malthusian Regime to the Demographic Transition", American Economic Review 90, 2000, pp. 806-28.

[6] Galor, O., Unified Growth Theory, Princeton, NJ: Princeton University Press, 2011.

[7] Human Development Report, "The Real Wealth of Nations: Pathways to Human Development", New York, 2010. Retrieved:

http://hdr.undp.org/en/content/humandevelopment-report-2010.

[8] Gerdtham G., \& Lothgren M., "On stationarity and cointegration of international health expenditure and GDP", Journal of Health Economics, vol. 19, issue 4, 2000, pp. 461-475.

[9] Goldin, C., Human capital, Handbook of Cliometrics, pg.17, Claude Diebolt and Michael Haupert editors, 2014.

[10] Hassan, M. S., \& Kalim, R., "The triangular causality among education, health and economic growth: A time series analysis of Pakistan", World Applied Sciences Journal, 18(2), 2012, pp. 196207.

[11] INSTAT, Albania In Figures 2018, Tirana, 2019. Retrieved: http://www.instat.gov.al/media/5651/albani a-in-figures-2018.pdf

[12] International Monetary Fund, 2017. Country Report No. 17/373 for Albania.
[13] Karim, D. O., "Health Expenditure and Economic Growth Nexus: An ARDL-Type Analysis for Nigeria". Imperial Journal of Interdisciplinary Research (IJIR), Vol. 2 (2), 2016, pp. 516.

[14] Kleiman, E., "The determinants of national outlay on health. In: Perlman (Ed.)", The Economics of Health and Medical Care, John Wiley \& Sons, New York. ,1974, pp 66-88.

[15] Parker, J., Theories of endogenous growth, Economics 314 Coursebook, Reed College, Chapter V., 2012.

[16] Newhouse, J.P., "Medical care expenditure: a cross national survey", The Journal of Human Recourses, Vol.12. No.1, 1997, pp. 111- 125.

[17] Pradhan, R.P., "The long run relation between health spending and economic growth in 11 OECD countries: Evidence from panel cointegration". International Journal of Economic Perspectives, 4(2), 2010, 427-438.

[18] Romer, P. M., "Increasing Returns and Long-Run Growth," Journal of Political Economy, 94(5), 1986, pp. 1002-1037.

[19] Romer, P. M., "Endogenous Technical Change," Journal of Political Economy 98(5), II, 1990, S71-S102.

[20] Trading Economics, Albania GDP Growth Rate. Retrieved:

https://tradingeconomics.com/albania/gdp-growth.

[21] World Bank 2019, "Rising Uncertainties", Western Balkans Regular Economic Report, No. 16|Fall 2019. 